\title{
Characterization of Multidrug Resistant Bacteria Isolated from Hospital Environment
}

\author{
Saba Irshad, Humaira Yasmeen* \\ Department of Microbiology and Molecular Genetics, The Women University Multan, Multan, Pakistan
}

\section{ABSTRACT}

Background: Unveiling of multidrug resistance in bacteria is becoming a global concern. It contributes as a main financial burden to treat infectious diseases especially in developing countries.

Objectives: This study was designed to determine the prevalence and resistance pattern of multidrug resistant bacteria from hospital soil.

Methodology: Using random soil sampling technique, bacterial isolates were obtained through dilution plate method. Antimicrobial screening of isolates was performed by Kirby Bauer disc diffusion method against a panel of 14 known antibiotics. Furthermore, strains were biochemically identified following Bergey's Manual of Determinative Bacteriology.

Results: A total of 44 isolates were successfully identified from 4 soil samples of different waste areas of hospital from Multan region. Bacillus spp. and Staphylococcus ssp. were prominent isolates in all the sites. Resistance among Bacillus spp. was high against ampicillin (91\%) and in Staphylococcus spp. against tetracycline (78\%). Out of total strains, 35 were found to be multidrug resistant.

Conclusion: Presence of drug residue in the hospital waste contributes to its resistance in bacteria. A substantial increase of multidrug resistance in hospital waste demands an effective management against drugs.

Keywords *Address of Correspondence Article info.

Bacillus spp., Staphylococcus ssp., MDR, humaira.6127@wum.edu.pk Received: July 2, 2019

hospital waste.

Cite this article: Irshad S, Yasmeen H. Characterization of Multidrug Resistant Bacteria Isolated

from Hospital Environment. RADS J Biol Res Appl Sci. 2019;10(2):94-101.

This is an Open Access article distributed under the terms of the Creative Commons Attribution License (http://creativecommons.org/licenses/by/4.0), which permits unrestricted use, distribution, and reproduction in any medium, provided the original work is properly cited.

\section{INTRODUCTION}

Antibiotics have been broadly used for the cure, delay and control of numerous infections. They act as bacteriostatic or bactericidal ${ }^{1,2}$. However, rapid development of resistance in bacteria via horizontal gene transfer has limited their use ${ }^{3,4}$. Multidrug-resistant (MDR) bacteria show resistance to more than three antimicrobial classes $^{5}$.

MDR is responsible for causing different infections i.e. bacteremia, pneumonia, meningitis, wound infection and urinary tract infection ${ }^{6}$. In humans, tuberculosis is the most common disease caused by MDR bacteria?. The magnitude of tuberculosis is increasing globally and one of the leading cause of death in Asia ${ }^{8}$. Pneumonia, urinary tract infection (UTI) and wound infections are preponderate infections caused by Pseudomonas aeruginosa ${ }^{9}$. However, Escherichia coli is the leading cause of UTI ${ }^{10}$. Similarly, enteric fever caused by Salmonella enterica serovars Typhi is responsible for 21 million illness and 200,000 deaths worldwide ${ }^{11}$. Enterobacteriaceae family is leading cause of infections in poultry and subsequent threat to humans. It is due to the risk for spread of these resistant genes through plasmids and clones from animals to humans ${ }^{12}$.

In Pakistan, the situation of resistant bacteria has become alarming for public health ${ }^{13}$. Colistin resistance in Klebsiella pneumoniae has become alarmingly high in Pakistan between 2010 and 201314. It has been observed that lack of knowledge about disease, self-medication, 
discontinuation of medicine, poor socio-economic conditions and improper diagnosis contributes significantly, in acquiring MDR infections ${ }^{15}$. In addition to these migration, gender, age and previous treatment history are also associated with the increased risk of several infections ${ }^{16}$.

New ways to overcome resistance have been devised such as combinations of two or more antibiotics, antibiotic and adjuvant combinations and screening of drugs approved previously ${ }^{17}$. Plants are explored for their potent antimicrobial activities, as they have been used as traditional medicine since ancient time ${ }^{18}$. The antimicrobial potential of plants is due to their secondary metabolites ${ }^{19}$.

The objective of the study was to isolate and characterize Gram positive resistant bacteria from hospital effluent especially soil, to determine antimicrobial resistant profiling and to explore common bacterial species among MDR.

\section{MATERIALS AND METHODS}

\section{Sampling Site}

Four $(n=4)$ soil samples from different hospitals situated in urban populated areas of Multan, Pakistan were collected under sterilized conditions from August to October 2016 at an interval of three weeks. They were collected from site of hospital where there was direct disposal of antibiotics in sterile plastic bags. Using sterile spatula, upper layer of soil was collected and soil conditions (soil color, texture, $\mathrm{pH}$, temperature) were observed before further processing.

\section{Isolation and Identification of Bacterial Isolates}

Soil samples were collected and brought to the laboratory under sterilized conditions. Serial dilutions were prepared in phosphate buffer saline and $0.1 \mathrm{ml}$ from 100 $10^{-3}, 10^{-5}$ and $10^{-7}$ was spread on nutrient agar plate. Following 24hours incubation, different colonies were observed that were further analyzed morphologically. Strains were biochemically identified as given in Bergey's Manual of Determinative Bacteriology20.

\section{Antimicrobial Susceptibility Testing}

Isolates were tested against 14 antibiotics. Results were interpreted according to guidelines of NCCLS Manual of Antimicrobial Susceptibility Testing.

For antimicrobial activity, isolated strains in broth were incubated at $37^{\circ} \mathrm{C}$ and turbidity was matched with 0.5 McFarland standard tube. The wavelength was adjusted between $0.08-0.1 \mathrm{~nm}$ at $625 \mathrm{~nm}$. Muller Hinton agar was used for antimicrobial susceptibility testing by standard Kirby-Bauer disc diffusion method. Tested antibiotics were chloramphenicol $(30 \mu \mathrm{g})$, clindamycin $(2 \mu \mathrm{g})$, gentamicin $(10 \mu \mathrm{g}), \quad$ vancomycin $\quad(30 \mu \mathrm{g}), \quad$ trimethoprimsulfamethoxazole $(5 \mu \mathrm{g})$, linezolid $(30 \mu \mathrm{g})$, quinupristin $(15 \mu \mathrm{g})$, oxacillin $(1 \mu \mathrm{g})$, ampicillin $(10 \mu \mathrm{g})$, ciprofloxacin $(5 \mu \mathrm{g})$, erythromycin $(15 \mu \mathrm{g})$, streptomycin $(10 \mu \mathrm{g})$, tetracycline $(30 \mu \mathrm{g})$ and fusidic acid $(10 \mu \mathrm{g})$. An inoculum $(75 \mu l)$ was spread gently on agar surface to form bacterial lawn and allowed to dry for 5-7minutes at room temperature. Discs were placed over surface of agar plate and placed in incubator for 24 hours at $37^{\circ} \mathrm{C}$. After incubation, zone of inhibition $(\mathrm{mm})$ was measured. Presence of zone around drug indicates sensitivity of bacterial strains against drug while absence of zone of inhibition indicates resistance ${ }^{21}$. The results were compered according to the Manual of Antimicrobial Susceptibility Testing. Strains were categorized as resistant $(R)$, intermediate $(I)$ and sensitive $(S)$ based on their zone of inhibition. Any strain that was resistant to more than three antibiotics was considered MDR.

\section{RESULTS}

A total of 56 bacterial strains were identified successfully but only 44 strains were left as 12 were lost during storage. Bacillus spp. $(21 / 44 ; 37 \%)$ and Staphylococcus spp. $(9 / 44 ; 16 \%)$ were more frequently present organisms in soil samples (Table 1).

Table 1. Frequency of Bacteria Isolated.

\begin{tabular}{cc|c}
\hline S. No. & Species & $\begin{array}{c}\text { Frequency } \\
(\mathbf{n = 4 4 )}\end{array}$ \\
\hline 1 & Bacillus spp. & $48 \%$ \\
\hline 2 & Staphylococcus spp. & $29 \%$ \\
\hline 3 & Streptococcus spp. & $9 \%$ \\
\hline 4 & Other & $14 \%$ \\
\hline
\end{tabular}


Other: Lactobacillus fermenti (7\%), Corynebacterium xerosis (5\%), Enterococcus spp. (2\%)

Table 2. Antibiotics and Their Resistance.

\begin{tabular}{|c|c|c|c|c|c|c|c|c|c|}
\hline \multirow{2}{*}{ S. No. } & \multirow{2}{*}{ Antibiotics used } & \multirow{2}{*}{$\begin{array}{c}\text { Concentration } \\
(\mu \mathrm{g})\end{array}$} & \multicolumn{3}{|c|}{ Standard (mm) } & \multicolumn{4}{|c|}{ Resistance among all samples } \\
\hline & & & $\mathbf{R}$ & I & S & S1 & S2 & S3 & S4 \\
\hline 1 & Ampicillin & $10 \mu \mathrm{g}$ & $\leq 13$ & $14-16$ & $\geq 19$ & $91 \%$ & $82 \%$ & $20 \%$ & $92 \%$ \\
\hline 2 & Clindamycin & $2 \mu g$ & $\leq 14$ & $15-20$ & $\geq 21$ & $27 \%$ & $36 \%$ & $10 \%$ & $25 \%$ \\
\hline 3 & Ciprofloxacin & $5 \mu \mathrm{g}$ & $\leq 15$ & $16-20$ & $\geq 21$ & $0 \%$ & $0 \%$ & $0 \%$ & $8 \%$ \\
\hline 4 & Chloramphenicol & $30 \mu \mathrm{g}$ & $\leq 12$ & $13-17$ & $\geq 18$ & $0 \%$ & $0 \%$ & $0 \%$ & $0 \%$ \\
\hline 5 & Erythromycin & $5 \mu g$ & $\leq 13$ & $14-22$ & $\geq 23$ & $27 \%$ & $18 \%$ & $10 \%$ & $17 \%$ \\
\hline 6 & Fusidic Acid & $10 \mu \mathrm{g}$ & $\leq 17$ & $18-21$ & $\geq 22$ & $82 \%$ & $64 \%$ & $40 \%$ & $67 \%$ \\
\hline 7 & Gentamicin & $10 \mu \mathrm{g}$ & $\leq 12$ & $13-14$ & $\geq 15$ & $0 \%$ & $0 \%$ & $0 \%$ & $0 \%$ \\
\hline 8 & Linezolid & $30 \mu \mathrm{g}$ & $\leq 20$ & $21-22$ & $\geq 23$ & $0 \%$ & $0 \%$ & $0 \%$ & $0 \%$ \\
\hline 9 & Oxacillin & $1 \mu \mathrm{g}$ & $\leq 10$ & $11-12$ & $\geq 13$ & $73 \%$ & $45 \%$ & $60 \%$ & $25 \%$ \\
\hline 10 & Quinupristin & $15 \mu \mathrm{g}$ & $\leq 15$ & $16-18$ & $\geq 19$ & $45 \%$ & $27 \%$ & $0 \%$ & $0 \%$ \\
\hline 11 & Streptomycin & $10 \mu \mathrm{g}$ & $\leq 11$ & $12-14$ & $\geq 15$ & $0 \%$ & $0 \%$ & $0 \%$ & $0 \%$ \\
\hline 12 & Tetracycline & $30 \mu \mathrm{g}$ & $\leq 14$ & $15-18$ & $\geq 19$ & $82 \%$ & $54 \%$ & $30 \%$ & $25 \%$ \\
\hline 13 & Trimethoprim & $1.25 \mu \mathrm{g}$ & $\leq 10$ & $11-15$ & $\geq 16$ & $54 \%$ & $73 \%$ & $30 \%$ & $58 \%$ \\
\hline 14 & Vancomycin & $30 \mu \mathrm{g}$ & $\leq 14$ & $15-16$ & $\geq 17$ & $45 \%$ & $9 \%$ & $10 \%$ & $8 \%$ \\
\hline
\end{tabular}

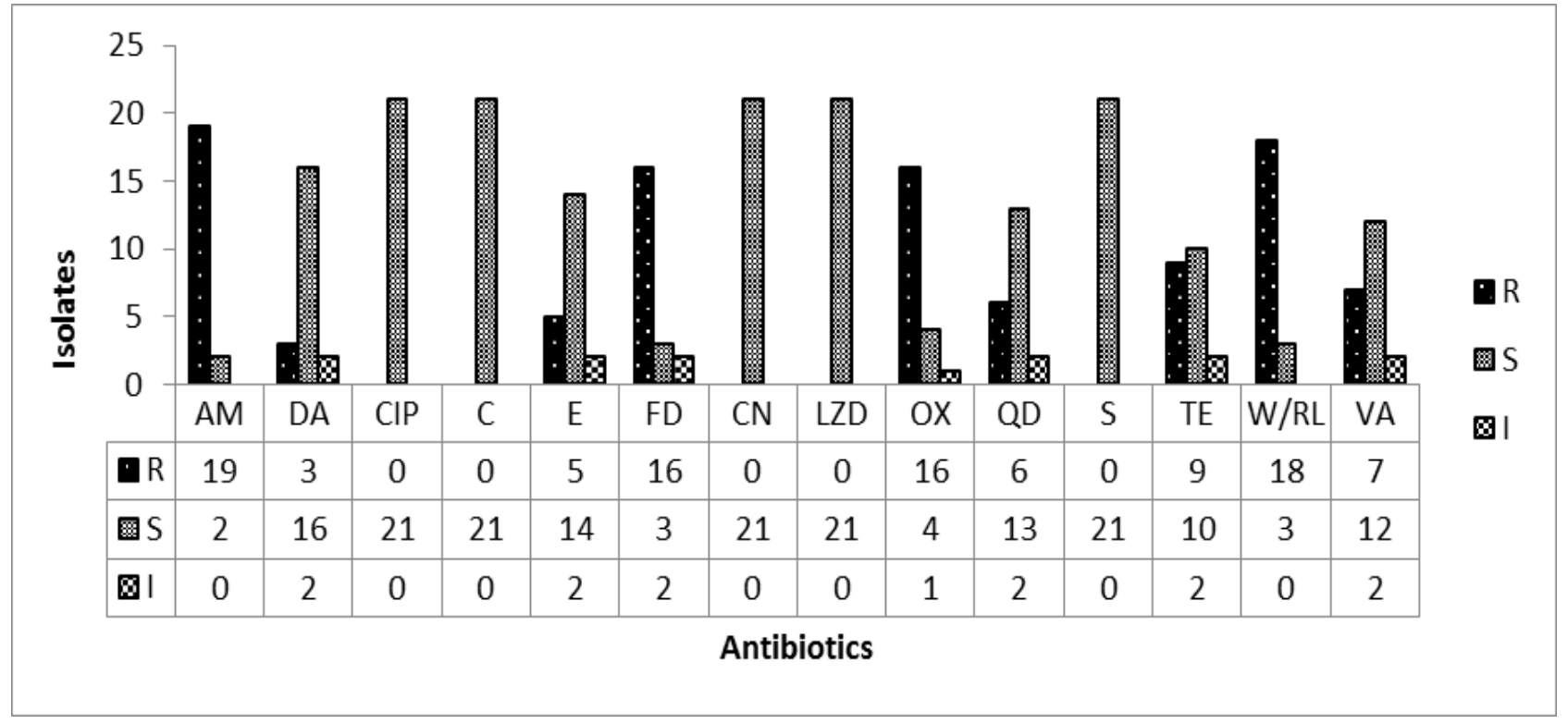

Figure 1. Resistance pattern of Bacillus spp.

\section{Antibiotic Susceptibility}

Initially, strains were screened for their antibiotic susceptibility. Out of total 44 strains, 35 were found to be
MDR, whereas 9 showed resistance to only one or two antibiotics. It was observed that 35\% Bacillus spp. isolates and $13 \%$ Staphylococcus spp. were resistant to 
more than three antibiotics. Lactobacillus fermenti was also resistant to more than three antibiotics and all of them were considered as MDR (Table 2).

\section{Susceptibility of Antibiotic to Bacillus spp.}

For Bacillus, the highest resistance was observed for ampicillin that is $91 \%$ (Figure 1).

After ampicillin, higher resistance observed was $86 \%$ for sulfamethoxazole-trimethoprim and $76 \%$ for both oxacillin and fusidic acid. In case of tetracycline, $43 \%$ of resistance was observed and 33\% resistance for vancomycin. Strains were least resistance against clindamycin (14\%) and erythromycin (24\%). Resistance pattern according to the class of antibiotic was also observed. It was observed that in Bacillus spp. the highest activity was observed against $\beta$-lactam antibiotics. Lowest activity was observed against aminoglycosides and fluoroquinolones.

\section{Susceptibility of Antibiotic to Staphylococcus spp.}

Nearly half $(40 \%)$ of the Staphylococcus spp. isolates were MDR

(Figure 2). As compared to Staphylococcus spp. Low resistance was observed in Bacillus spp. Staphylococcus spp. Were found out highly resistant against tetracycline
(78\%) and ampicillin (67\%). Only 44\% resistance was observed in case of oxacillin. In case of Bacillus spp. it was $76 \%$. Resistance to clindamycin, sulfamethoxazoletrimethoprim and fusidic acid was 33\% each. However, resistance against erythromycin and quinopristin was $22 \%$. Bacterial isolates were least resistant against vancomycin (11\%). According to antibiotic classes the highest activity was observed against tetracycline (78\%) and lowest by glycopeptide (67\%) antibiotics.

\section{Susceptibility of Antibiotic to Other Isolated Species}

It had been observed that $50 \%$ of Streptococcus spp. were MDR (Figure 3). Interestingly, all Streptococcus isolates were resistant against ampicillin, fusidic acid and erythromycin. While $75 \%$ of isolates were resistant against quinopristin and sulfamethoxazole-trimethoprim and $50 \%$ of the isolates were resistant to oxacillin. Low resistance was observed against tetracycline that was $25 \%$. Lowest resistance was observed against ciprofloxacin, linezolid and streptomycin.

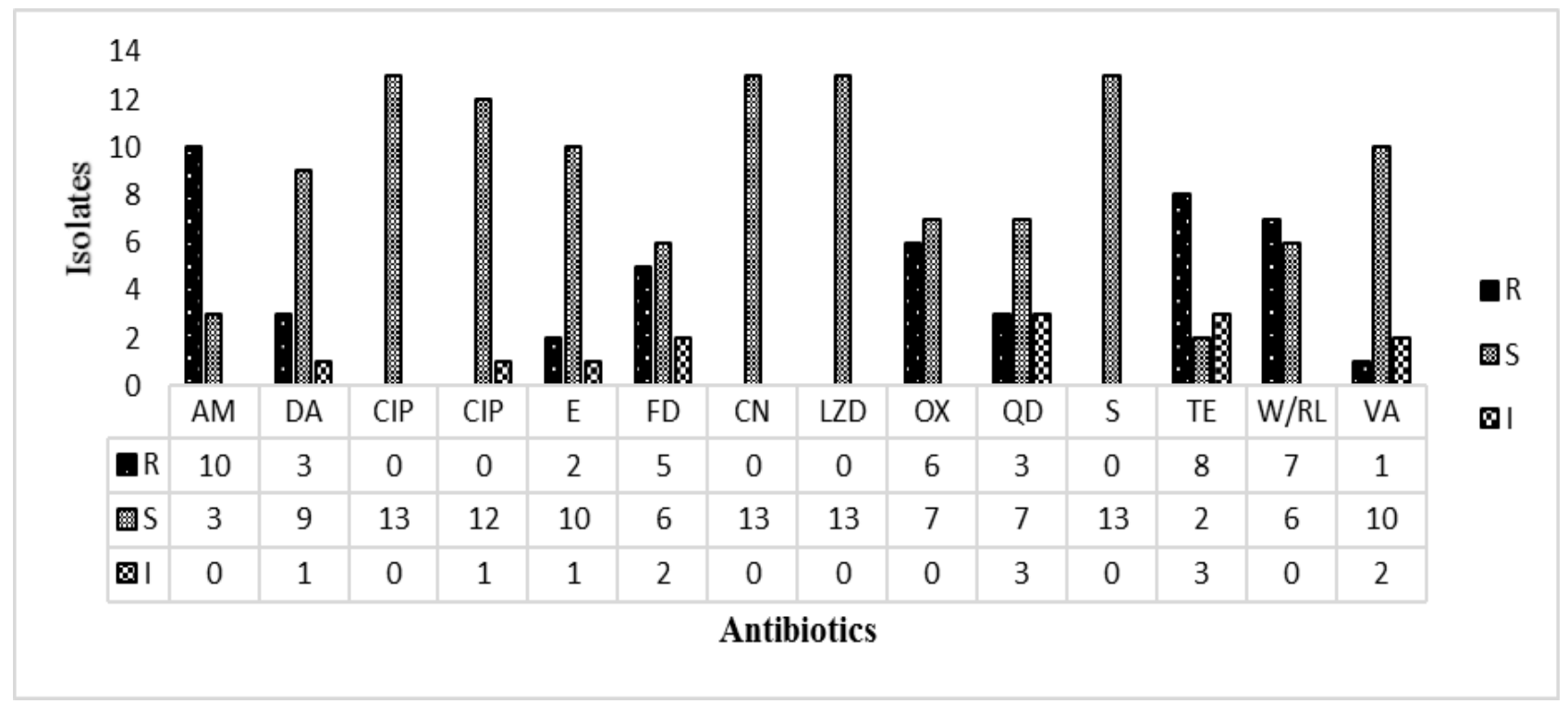

Figure 2. Resistance pattern of Staphylococcus spp. 


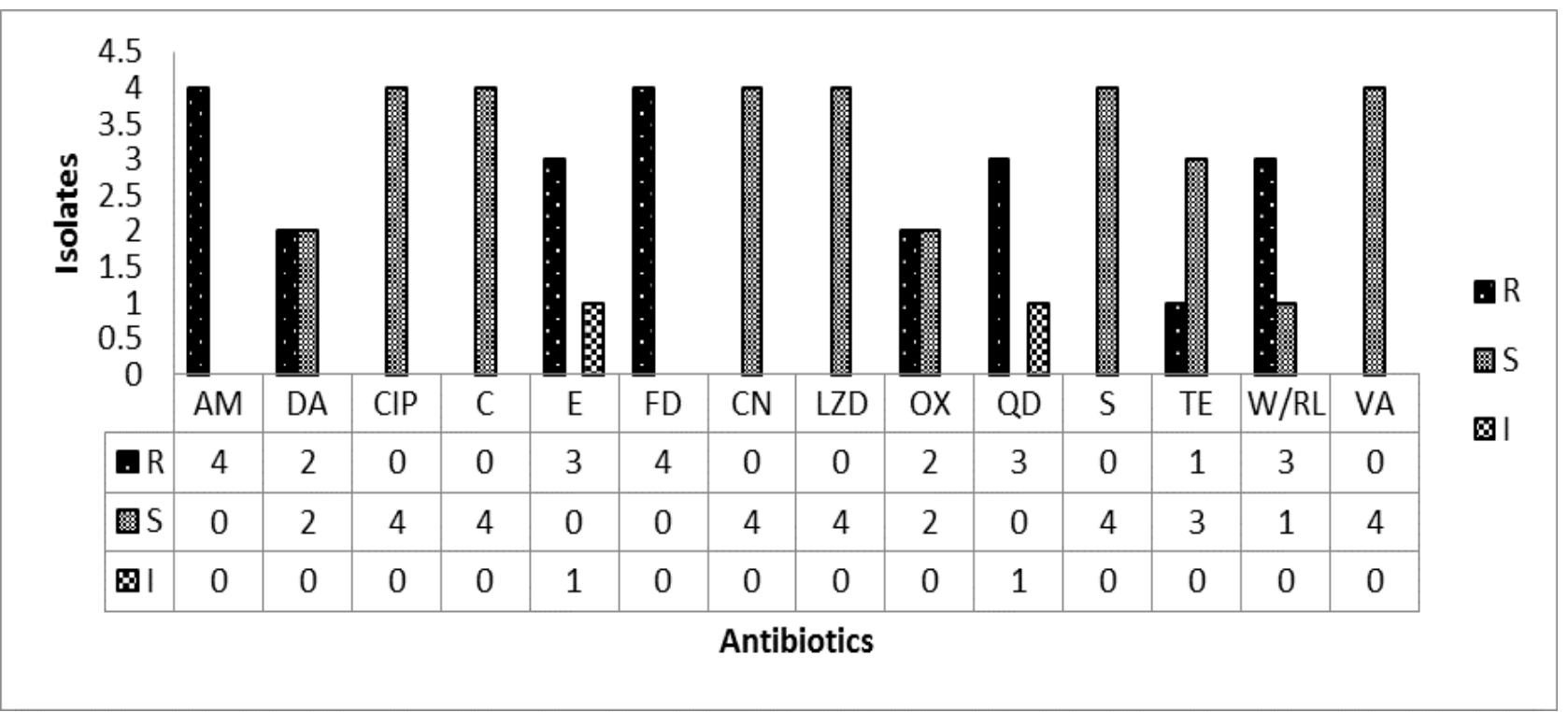

Figure 3. Resistance pattern of Streptococcus spp.

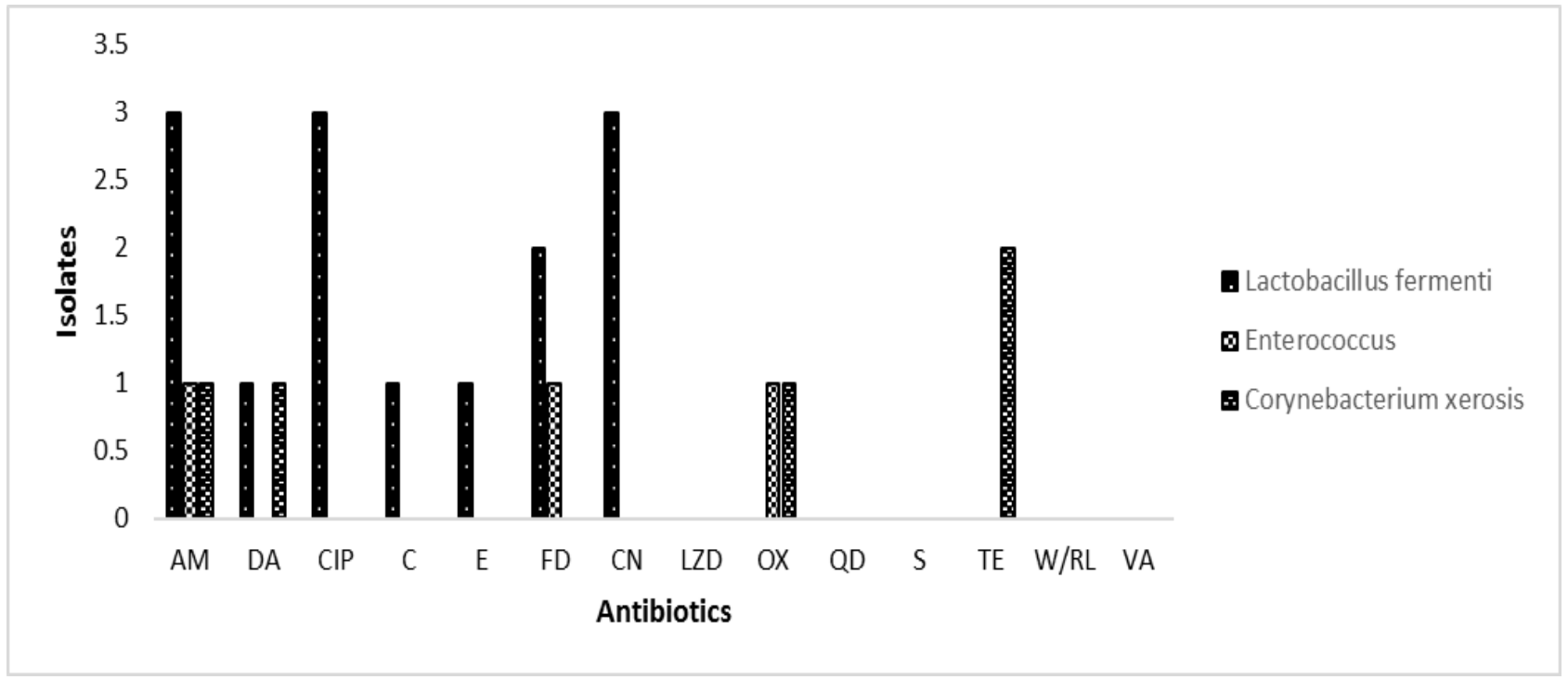

Figure 4. Resistance pattern of other isolated spp.

In case of Lactobacillus fermenti, all isolates were MDR (100\%) (Figure 4). They showed $100 \%$ resistance to ampicillin, fusidic acid and erythromycin and $67 \%$ of the isolates show resistance to oxacillin.

However, only $33 \%$ resistance was observed against tetracycline, vancomycin and sulfamethoxazoletrimethoprim. Isolates showed least resistance against clindamycin, Quinopristin, streptomycin, chloramphenicol and linezolid. Half of the Corynebacterium xerosis isolates were MDR (50\%) were resistant to tetracycline while $50 \%$ isolates were found resistant against clindamycin, oxacillin and ampicillin. Corynebacterium xerosis isolates were sensitive to sulfamethoxazole-trimethoprim, vancomycin, fusidic acid and erythromycin. Enterococcus spp. was also MDR showed resistance to only ampicillin, fusidic acid and oxacillin. 


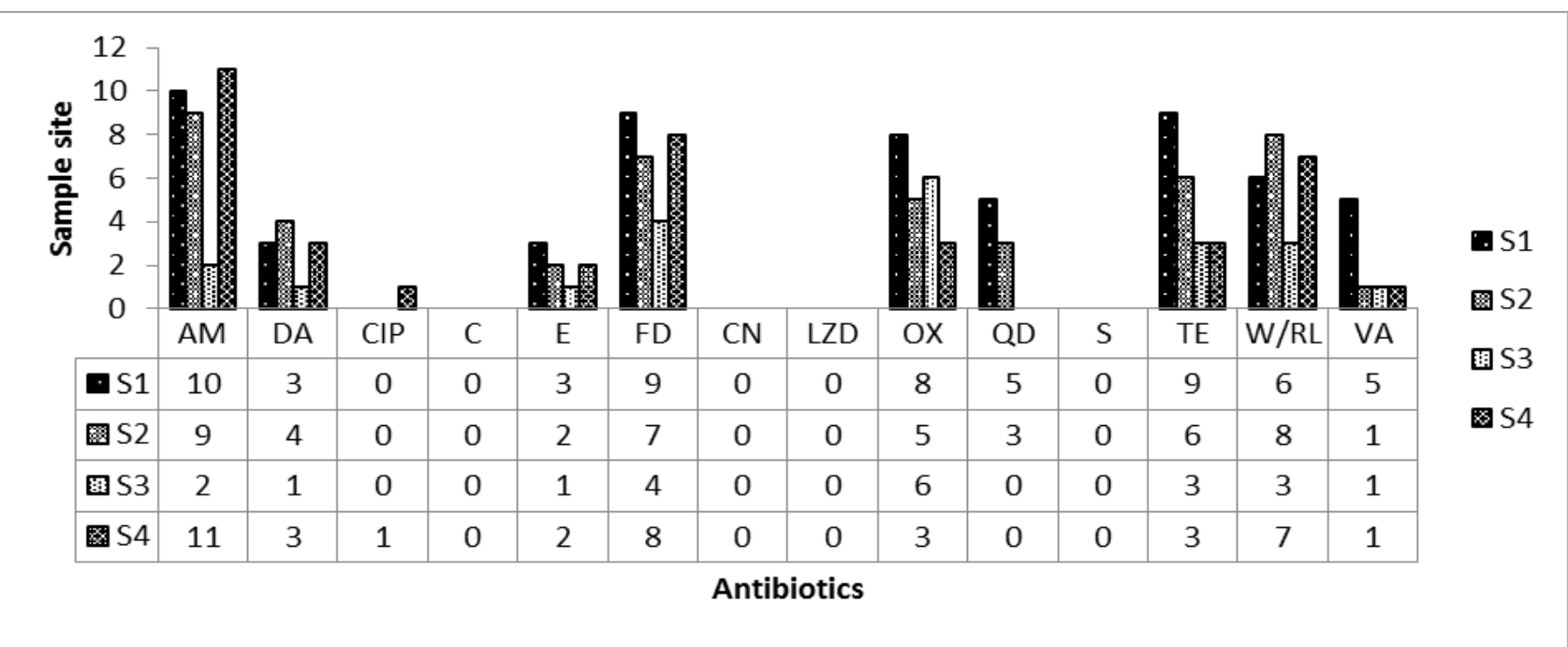

Figure 5. Resistance pattern among sample site.

\section{Resistance Patterns Among Different Sample Sites}

The pattern of antibiotic resistance of each sample site was compared to evaluate the effect of hospital waste in resistance development (Figure 5). Resistance pattern of Bacillus spp. varied in different samples for different antibiotic.

Same was true for other antibiotics. The resistant pattern of bacterial species varies in samples. It showed that sampling site has impact on diversified resistant development in bacteria.

\section{DISCUSSION}

In developing countries like Pakistan, irrational use of antibiotics has contributed in continuous increase in drug resistant ${ }^{22}$. Hospital operation theatre, ICU and patient ward are set up potent platform for spreading of pathogens among individuals ${ }^{23}$. Microbial pollution from hospital waste is also becoming an increasing threat to the public health as the human population expanding with time. Therefore, for public health reasons continuous assessment of hospital area is of prime importance ${ }^{24}$.

Current study was carried out to isolate Gram positive bacteria and determine MDR frequency in them. Moges et al. (2014) had reported both gram positive and gram negative MDR. Like Diab et al. ${ }^{25}$, Manyahi et al. ${ }^{26}$ and Moges et al. ${ }^{27}$ reported higher percent of gram negative than gram positive as MDR. However, Modi et al. ${ }^{28}$ reported slightly different results. In their study, although both gram positive and gram negative MDR reported were present but percentage of gram positive was higher. High number of gram negative in hospital samples can be attributed to their possible role in serious nosocomial infections.

High percentage of MDR can be attributed to the fact that hospital waste is disposed without any treatment. Prolonged exposure of bacteria in hospital contaminated sites assisted in development of MDR efflux pump and therefore in development of resistance. Presence of resistant isolates in environment serves as a possible reservoir for transfer of resistant genes into other highly infectious pathogens ${ }^{22}$. The resistant pattern of isolates varied and maximum resistance was observed against ampicillin. Resistance pattern of Bacillus spp. and Staphylococcus spp. showed variation as Bacillus spp. showed $91 \%$ resistance against ampicillin and Staphylococcus spp. showed $67 \%$ resistance against ampicillin. The susceptibility pattern of Bacillus spp. and Staphylococcus spp. was varied. Although resistance was higher in Bacillus spp. as compared to Staphylococcus spp. It may be due to the fact that Bacillus spp. is ubiquitous, it has developed adaptive strategies to subsist in diverse environments via the production and secretion of several genetically encoded molecules. A positive correlation was observed in sampling site and the resistance pattern among isolates. High number of resistant strains in sampling site 1 and 2 is due to their sampling sites. These were the sites where hospital waste disposed directly. Therefore, direct disposal of hospital 
waste could contribute to the development of antibiotic resistance in isolates ${ }^{29}$.

\section{CONCLUSION}

Antibiotics are saving millions of lives but on the other hand their misuse and overuse is making them less effective due to development of resistance among bacterial species. In above study, out of total 44 strains 35 were found to be MDR. Our result indicate a possible relation that multidrug resistance development in hospital waste is due to direct disposal of untreated hospital waste, that could spread MDR so efforts must be taken to prevent dumping of antibiotics containing waste into the environment.

\section{LIST OF ABBREVIATIONS}

$\begin{array}{ll}\text { AM } & \text { Ampicillin } \\ \text { DA } & \text { Clindamycin } \\ \text { CIP } & \text { Ciprofloxacin } \\ \text { C } & \text { Chloramphenicol } \\ \text { E } & \text { Erythromycin } \\ \text { FD } & \text { Fusidic Acid } \\ \text { CN } & \text { Gentamicin } \\ \text { LZD } & \text { Linezolid } \\ \text { OX } & \text { Oxacillin } \\ \text { QD } & \text { Quinopristin } \\ \text { S } & \text { Streptomycin } \\ \text { TE } & \text { Tetracycline } \\ \text { SXT } & \text { Sulfamethoxazole } \\ \text { VA } & \text { Vancomycin } \\ \text { R } & \text { Resistant } \\ \text { I } & \text { Intermediate } \\ \text { S } & \text { Sensitive } \\ \text { MDR } & \text { Multi Drug Resistance } \\ \text { UTI } & \text { Urinary Tract Infection }\end{array}$

\section{REFERENCES}

1. Yuan $M, Y u ~ Y, L i ~ H R$, Dong N, Zhang XH. Phylogenetic diversity and biological activity of actinobacteria isolated from the Chukchi Shelf marine sediments in the Arctic Ocean. Mar Drugs. 2014; 12(3):1281-97.
2. Nagpal S. Antibiotics use and abuse. J Pharm Res. 2017; 16(1).

3. Piddock LJ. Teixobactin, the first of a new class of antibiotics discovered by iChip technology? J Antimicrob Chemother. 2015; 70(10):2679-80.

4. Ventola CL. The antibiotic resistance crisis: Part 1: Causes and threats. Pharm Ther. 2015; 40(4):277-83.

5. Saha M, Sarkar S, Sarkar B, Sharma BK, Bhattacharjee S, Tribedi P. Microbial siderophores and their potential applications: A review. Environ Sci Pollut R. 2016; 23(5):3984-99.

6. Singh S, Agarwal RK, Tiwari SC, Singh H. Antibiotic resistance pattern among the Salmonella isolated from human, animal and meat in India. Tropical animal health and production. 2012; 44(3):665-74.

7. Sandhu GK. Tuberculosis: Current situation, challenges and overview of its control programs in India. J. Glob Infect Dis. 2011; 3(2):143-50.

8. Akhtar AM, Arif MA, Kanwal S, Majeed S. Prevalence and drug resistance pattern of MDR TB in retreatment cases of Punjab, Pakistan. J Pak Med Assoc. 2016; 66(8):989-3.

9. Tanvir R, Ather S, Shariq A, Tanvir SB, Ahmed S, Hussain A. Susceptibility pattern of Pseudomonas aeruginosa to aminoglycosides (Gentamicin and Amikacin) in a tertiary care hospital of Karachi, Pakistan. Eur J Biotechnol Biol Sci. 2015; 3(7):31-4.

10. Ullah F, Malik S, Ahmed J. Antibiotic susceptibility pattern and ESBL prevalence in nosocomial Escherichia coli from urinary tract infections in Pakistan. Afr J Biotechnol. 2009; 8(16):3921-6.

11. Hasan R, Zafar A, Abbas Z, Mahraj V, Malik F, Zaidi A. Antibiotic resistance among Salmonella enterica serovars Typhi and Paratyphi A in Pakistan (20012006). J Infect Dev Ctries. 2008; 2(04):289-94.

12. Zibandeh S, Sharifiyazdi H, Asasi K, Abdi-Hachesoo $\mathrm{B}$. Investigation of tetracycline resistance genes in Escherichia coli isolates from broiler chickens during a rearing period in Iran. Vet Arhiv. 2016; 86(4):56572.

13. llyas $H$, llyas $S$, Ahmad SR, Nawaz MC. Waste generation rate and composition analysis of solid waste in Gujranwala city Pakistan. Int. J. Waste Resour. 2017; 7(297):2-7.

14. Crawford MA, Timme R, Lomonaco S, Lascols C, Fisher DJ, Sharma SK, et al. Genome sequences of multidrug-resistant, colistin-susceptible and-resistant Klebsiella pneumoniae clinical isolates from Pakistan. Genome Announc. 2016; 4(6):e01419-16.

15. Sharma $P$, Mathur N, Singh A, Sogani M, Bhatnagar $\mathrm{P}$, Atri $\mathrm{R}$, et al. Monitoring hospital wastewaters for their probable genotoxicity and mutagenicity. Environ Monit Assess. 2015; 187(1):4180-9.

16. Sethi S, Sharma D, Mehta SD, Singh B, Smriti M, Kumar B, et al. Emergence of ciprofloxacin resistant Neisseria gonorrhoeae in North India. Indian J Med Res. 2006; 123(5):707-10. 
17. Tran NH, Reinhard M, Gin KY. Occurrence and fate of emerging contaminants in municipal wastewater treatment plants from different geographical regions-a review. Water Res. 2018; 133:182-207.

18. Chandra M. Antimicrobial activity of medicinal plants against human pathogenic bacteria. International $\mathrm{J}$ Biotech Bioeng Res. 2013; 4(7):653-8.

19. Gull I, Saeed M, Shaukat H, Aslam SM, Samra ZQ, Athar AM. Inhibitory effect of Allium sativum and Zingiber officinale extracts on clinically important drug resistant pathogenic bacteria. Ann Clin Microbiol Antimicrob. 2012; 11(1):8-13.

20. Brown JH. Bergey's manual of determinative bacteriology. Am J Public Health (1939); 404-5.

21. Yasmeen $\mathrm{H}$, Hasnain $\mathrm{S}$. In vitro antioxidant effect of Camellia sinensis on human cell cultures. Pak J Pharm Sci. 2015; 28(5):1573-81.

22. Rabbani MA, Howlader MZ, Kabir Y. Detection of multidrug resistant (MDR) bacteria in untreated waste water disposals of hospitals in Dhaka city, Bangladesh. J Glob Antimicrob Resist. 2017; 10:1205.

23. Piddock LJ. Clinically relevant chromosomally encoded multidrug resistance efflux pumps in bacteria. Clin Microbiol Rev. 2006; 19(2):382-402.

24. Maloo A, Fulke AB, Mulani N, Sukumaran S, Ram A. Pathogenic multiple antimicrobial resistant
Escherichia coli serotypes in recreational waters of Mumbai, India: A potential public health risk. Environ Sci Pollut R. 2017; 24(12):11504-17.

25. Diab AM, Al-Turk IM, Ibrahim MK, Al-Zhrany KD. Tracing of gram-negative antibiotic-resistant bacteria in hospitals final effluent at Al-Madinah AlMounwwarah. J Taibah Univ Sci. 2008; 1(1):24-33.

26. Manyahi J, Tellevik MG, Ndugulile F, Moyo SJ, Langeland N, Blomberg B. Molecular characterization of cotrimoxazole resistance genes and their associated integrons in clinical isolates of gramnegative bacteria from Tanzania. Microb Drug Resist. 2017; 23(1):37-43.

27. Moges F, Endris M, Belyhun Y, Worku W. Isolation and characterization of multiple drug resistance bacterial pathogens from waste water in hospital and non-hospital environments, Northwest Ethiopia. BMC Res Notes. 2014; 7(1):215-20.

28. Modi SR, Lee HH, Spina CS, Collins JJ. Antibiotic treatment expands the resistance reservoir and ecological network of the phage metagenome. Nature. 2013; 499(7457):219-22.

29. Pandey A, Afsheen FA, Tiwari SK. Isolation and characterization of multi drug resistance cultures from waste water. J Pharm Biomed Sci. 2011;13(14):1-7. 